\title{
The Camp of the Mormon Handcart Brigade
}

\author{
By O. J. Prurtt
}

The long pause of the Mormon hosts at Council Bluffs, after their slow and distressing march through Iowa, following the hurried flight from Nauvoo, Illinois, gathering resources for the difficult journey to Utah, marked this point in the midwest as important to them.

A few years ago, Henry K. Peterson, president of the Pottawattamie County Historical Society, and the writer interviewed Mrs. Smith. She was the oldest living daughter of William Garner-Uncle Billy to many people. Mrs. Smith then was upwards of eighty years old. Her faculties were very good for one of that age. She could recall many of the incidents of her famous father.

Mr. Garner joined the Mormon Battalion on their long march to Utah from Council Bluffs, and he continued on to California. We were shown a skillet carried in this journey. It was during the Mexican war. Arriving in California and almost without funds, $\mathrm{Mr}$. Garner went to work as a millwright at the Sutter Mill where gold was first discovered. He accepted his wages in gold coin and gold dust, which he carried on his person beneath his clothing. He purchased a mule for the long trek back to Florence, Nebraska, where his wife and children resided. This was in 1850.

On the way, for two days and nights, he had as a companion an Indian who rode a mustang pony and said he was going to his people in Idaho. The Indian was a Blackfoot. In camp at night, Mr. Garner was very uneasy and fearing the Indian would attempt to rob him of the gold, he slept with a Colts sixshooter handy. The second night the Indian arose after lying down for a short time. Something had disturbed the 
horse and mule and the Indian went to see. This was the alarm Mr. Garner feared and was expecting, but it proved unimportant. In crossing the Nevada desert, Mr. Garner had to apportion his rations and the mule had to go a full day and night without water. He was very fortunate in having a map that gave the locations where water and fuel were to be had along the trail. He came by the way of Salt Lake.

During his absence, Mrs. Garner had a very trying time. She had sent her hired man to Missouri to bring back a load of corn to be ground into meal. The Mormons confiscated the worn wagon and oxen. From that day on she hated all Mormons. This part of her experiences was published by W. J. Leverett, who printed a paper during the Trans-Mississippi Exposition in Omaha 1898-99.

Mr. Garner kept a diary of the entire trip to and from California, but it has been lost. Inquiry was made of a younger sister living in California to learn if she possessed it, but she did not. All to be learned at this late date of the events of Mr. Smith's trip is the word of Mrs. Smith. She lives with Mark, her son, on a farm near the old Garner homestead. It was Mark Smith that showed us the location of the Mormon camp of the handcart brigade. It was located on a south slope of land along the Mosquito creek bottom and near the site of the Garner woolen mill powered by the water of the creek.

The Garner homestead is cased inside with lumber cut from the native black walnut timber. The writer has seen inside the house many times. His last visit to the house was when Mr. Wilbur Hubbard lived on the place. Garner township is named in honor of William Garner. Near the place is the old Garner cemetery where lie many of the pioneers.

The highway past the old homestead now parallels the Rock Island railroad. It is some distance now from the original road. The house sets back some distance from the dirt road on a rise of land and behind it is the grove of native timber. On the old highway is a 
living spring beside the road that in the years past has quenched the thirst of many a man, woman and beast. The writer has lain down "belly buster" many times to drink of the water and he has filled the radiator of an old jalopy there.

Having crossed the Nevada desert many times by modern methods, one has only to read of trips across that desert in old times to appreciate what it was like astride a mule and alone. It was a great risk of life, either by loss of sense of direction or being deprived of water and food. Today it is the largest expanse of apparent nothing that one will ever be privileged to see. Mountains, sage brush, Joshua trees and giant cacti abound, but little active life. Even the tiny woodpeckers have a test of endurance to survive. They rear and brood their young in holes pecked in the giant cacti and feed on millers and bugs. Ever and anon, at this late date, skeletons of human beings are found, that long have remained in position of the time of death. No vestigial evidence now exists that they ever wore clothing, save for buttons. The skeletons of soldiers and settlers, with their conestoga wagons, who lost their lives in the north part of the state in the early sixties, are here found.

The handcart brigade pulled out in the face of a coming winter. An artist portrays the motley sight with a pen sketch. In single file with children atop the load, the wife pushing, the father or son pulling; the scene is a panorama, with a topography of rolling land. Far to the west, is the pale outline of the horizon and to the rear a dim shadow of fading memories. Today only a few of the handcarts exist in Salt Lake City and the intrinsic value now is very great. None can be purchased.

\section{Falsehood Always Ignoble}

When I meet falsehood, I care not how great the person proclaiming it, I do not try to like it, or believe it, or mimic the fashionable prattle of the world about it.-William Henry Hudson. 
Copyright of Annals of Iowa is the property of State of Iowa, by \& through the State Historical Society of Iowa and its content may not be copied or emailed to multiple sites or posted to a listserv without the copyright holder's express written permission. However, users may print, download, or email articles for individual use. 